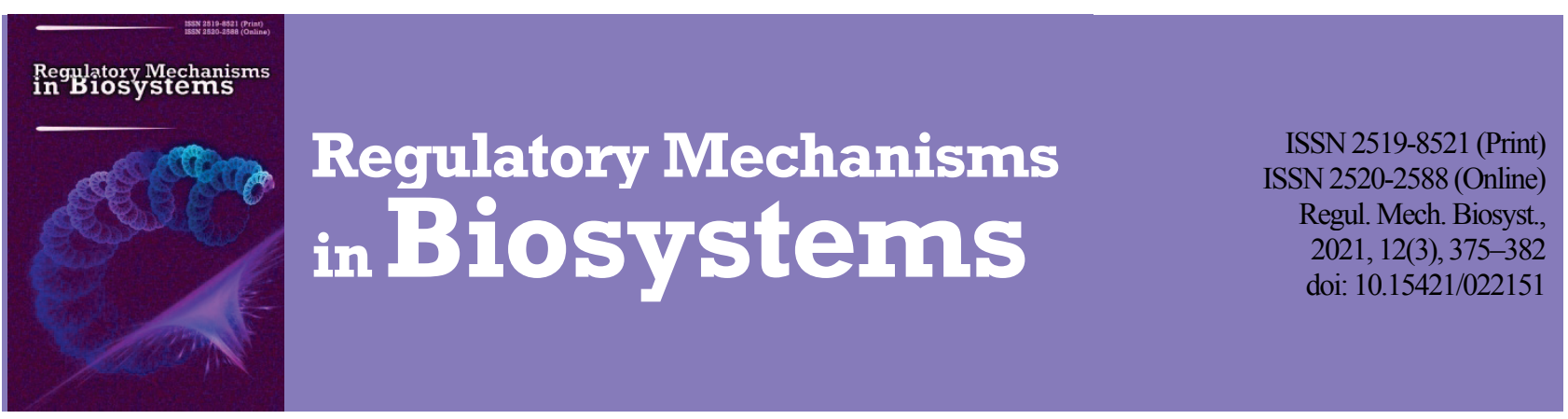

\title{
Systematic treatment of morphological fruit types in plants of the class Liliopsida of the flora of Ukraine
}

\author{
A. V. Odintsova*, O. S. Fishchuk**, K. I. Scrypec*, I. M. Danylyk*** \\ *Ivan Franko National University of Lviv, Lviv, Ukraine \\ **Lesya Ukrainka Volyn National University, Lutsk, Ukraine \\ ***Institute of Ecology of the Carpathians, Lviv, Ukraine
}

Article info

Received 12.07.2021

Received in revised form 15.08 .2021

Accepted 17.08.2021

Ivan Franko National University of Lviv,

Hrusherskogo st., 4 ,

Lviv, 79005 , Ukraine

Tel.: +38-032-239-41-37.

E-mail:amorpha@ukr.net

Lesya Ukrainka

Volyn National University

Volipr., 13,

Lutsk, 43025, Ukraine.

Tel.: +38-066-310-81-07.

E-mail:dracaenaok@ukr.net

Institute of Ecology

of the Carpathians,

Kozelnytska st., 4 ,

Lviv, 79026, Ukraine.

Tel.: + 38-067-311-60-65.

E-mail:idanylyk@ukr.net
Odintsova, A. V., Fishchuk, O. S., Scrypec, K. I., \& Danylyk, I. M. (2021). Systematic treatment of morphological fruit types in plants of the class Liliopsida of the flora of Ukraine. Regulatory Mechanisms in Biosystems, 12(3), 375-382. doi:10.15421/022151

In this review, the scope of morphological diversity of fruits within the class Liliopsida belonging to the flora of Ukraine compared to the world flora diversity was analyzed. For the first time, the taxonomic diversity of monocot plants of the flora of Ukraine was analyzed, which includes 235 genera and about 1050 species, and the distribution of fruit types in the largest monocot families revealed. It was found that among monocot plants of the world flora, as also of the Ukrainian flora, more than $70 \%$ of generic and species diversity is taken up by the Orchidaceae, Poaceae, and Cyperaceae families having dry uniform fruits: inferior capsule (Orchidaceae) and one-seeded enveloped fruit (Poaceae and Cyperaceae). An annotated list of morphological fruit types was compiled for all 38 families of the natural and cultural flora of monocot plants of Ukraine. Among 12 families of the subclass Alismatidae, apocarpous polymerous or trimerous fruits, mostly with one-seeded fruitlets, occur in six families (Alismataceae, Butomaceae, Potamogetonaceae, Ruppiaceae, Scheuchzeriaceae, Zannichelliaceae). In 12 of 16 families of the subclass Liliidae, trimerous capsules are the most common (Agapanthaceae, Agavaceae, Alliaceae, Amaryllidaceae, Asphodelaceae, Colchicaceae, Hemerocallidacae, Hyacinthaceae, Iridaceae, Liliaceae, Melanthiaceae, Orchidaceae), while in six families berry-like fruit occurs in all members or in the single genus (Asparagaceae, Ruscaceae, Dioscoreaceae, Melanthiaceae (Paris), Liliaceae (Streptopus), Smilacaceae). Among 10 families of the subclass Commelinidae, in four families superior dry one-seeded fruits occur (Cyperaceae, Poaceae, Sparganiaceae, Typhaceae), while another four families have trimerous capsules (Cannaceae, Commelinaceae, Juncaceae, Pontederiaceae). In general, the most typical fruit on the familial taxonomical level is the capsule (17 families), berries occur in 10 families, aggregate fruits and one-seeded fruits are represented each in seven families, while the rarest fruit type is the schizocarp (Juncaginaceae). No monomerous follicles, poricide and operculate capsules, winged fruits and loments were found. The most controversial fruit types are found in two groups of families, for both of them the problem is the gynoecium type. These are families with one-seeded fruit (Araceae (Lemna), Cyperaceae, Hydrocharitaceae (Najas), Poaceae, Sparganiaceae, Typhaceae, Zosteraceae) and families with initial carpel fusion (Hydrocharitaceae (Stratiotes), Juncaginaceae, Melanthiaceae (Veratrum), Scheuchzeriaceae, Tofieldiaceae). As a result of our work, the key and the most relevant areas of carpological studies in Ukraine were defined, particularly, unifying the terminology, examination of the anatomical structure of the pericarp, revealing of the evolutionary and ecological aspects of fruit morphology.

Keywords: monocots; Alismatidae; Liliidae; Commelinidae; carpology; capsular fruit.

\section{Introduction}

Fruit is defined as a terminal stage of differentiation and specialization of the gynoecium together with persistent floral parts (Teryokhin, 2000). Although fruit characters are widely used in systematics (Cronquist, 1981; Takhtajan, 1987, 2009), this happens substantially less often than usage of the flower characters. This is due to the fact that fruit structure often undergoes parallel evolution and convergence in many clades, which makes it difficult to use carpological data in evolutionary morphology and systematics. It was stated that fruit are too versatile and have too many aspects to be divided into strict categories (Pijl, 1982). However, morpho-anatomical fruit structure is a combination of many apomorphic characters of plant species, related to their reproductive system, which emphasized the need to reveal homologous fruit features in different species and identify trends of fruit evolution (Bobrov et al., 2009). Such examinations are not possible without an unequivocal and adequate terminology on fruit structure and typology.

In Ukraine research on fruit structure began in the 1980s and has been carried out mainly in the relation to the systematics of defined families or plant introduction (Ziman \& Bulakh, 2013). Predominantly, anatomical features and ultrastructure of fruit surface were studied, as also taxonomically significant morphological fruit traits. The latest monograph studies on fruit in plants of the flora of Ukraine were carried out on the genus Campanula (Dremliuga, 2013) and the Brassicaceae family (llyinska, 2016). However, generalized researches on morphological diversity and classification of fruits were absent. The necessity of such research is obvious to plant taxonomists, phytocoenologists, and ecologists using data on fruit adaptive and evolutionary-marker features in their studies. In this relation, in our neighbouring states structural carpological studies are actively proceeding in the XXI century, for instance, Slovakian botanists have published an atlas of seed and fruit morphology with descriptions of seeds and indehiscent fruits of 4,800 species (Bojňanský \& Fargašová, 2007); in Poland, a bibliography of carpological works was published with more than 140 cited sources from Polish botanists (Latowski et al., 2015). Russian botanists are developing a morphogenetic approach and study of pericarp anatomy (Bobrov et al., 2009; Kravtsova, 2015; Bobrov \& Romanov, 2019).

Contemporary researches pay great attention to ecology and consortial relations of plants with frugivorous animals (Jordaan et al., 2011; Karimi et al., 2020; Sena et al., 2021), particularly, the significant role of 
fleshy fruits of various woody plants in the diet of forest birds has been revealed (Pesotskaya et al., 2020). The fruit structure is studied in relation to the reproduction of plant species (Lebedeva et al., 2020), dispersion of plants by hydrochory (Boedeltje et al., 2008; Favre-Bac et al., 2017; Behren von \& Yeakley, 2020), genetic regulation of fruit development (Dardick \& Callahan, 2014), the evolutionary and adaptive significance of fleshy fruit metabolites (Balaguera-Lopez et al., 2020; Famiani et al., 2020) and fruit scent (Nevo \& Ayasse, 2020).

The problem of fruit classification and evolution is closely related to the problems of the classification and evolution of the gynoecium, a structure bearing many adaptive and evolutionary significant fruit traits. In this article, we intend to analyze the known data on morphological fruit diversity within monocotyledonous plants, to compile fruit names applied to one taxon in home and foreign literature, to evaluate the occurrence of diverse morphological fruit types of the flora of Ukraine within the class Liliopsida Batsch, to reveal the most common fruit types, as also families of the flora of Ukraine having the most controversial fruit types with a view to their further investigation.

\section{Taxonomical diversity of the class Liliopsida in the flora of Ukraine and main fruit types}

The class Liliopsida in the world flora comprises 78 families, 2612 genera, and from 56310 (Thorne \& Reveal, 2007) to 60100 species (www.mobot.org/MOBOT/research/APweb). Monocotyledonous plants of the flora of Ukraine encompass 38 families, recognized by Mosyakin (2013) or 30 families sensu Chase et al. (2016), which is about $40 \%$ of the world monocot familial diversity. The extent of the class Liliopsida belonging to the flora of Ukraine was defined including the cultivated taxa, as stated in the work of Mosyakin (2013). According to the published data (Mosyakin \& Fedoronchuk, 1999), the monocot flora of Ukraine includes 235 genera and about 1050 species, which is less than $10 \%$ of genera and only about $1.5 \%$ of species of the world monocot flora. Taxonomical diversity of Liliopsida is five times less than dicotyledonous diversity (Thorne \& Reveal, 2007), for this reason, we may expect a less expressed structural diversity of fruits within Liliopsida compared to the general diversity of angiosperm fruits. Within the class Liliopsida of the world flora, the first places in species richness are occupied by the families Orchidaceae, Poaceae, and Cyperaceae, embracing in total $74 \%$ of species and $70 \%$ of generic monocot richness. These families are characterized by uniform dry fruits: inferior capsule (Orchidaceae) and one-seeded enveloped fruits (Poaceae and Cyperaceae, Table 1). This fact results in the quantitative prevalence of corresponding fruit types in the class Liliopsida and even further restricts the limits of expected fruit diversity in the rest of the monocot taxa. Among the largest monocot families of the world flora, dry capsular fruits prevail, being the dominant or the most common fruit type in six of ten families. Within the top listed families, one-seeded fruits occur in addition to Poaceae and Cyperaceae also in Arecaceae and Araceae (in particular, Lemnaceae, included in Araceae). Berry-like fruits occur in some Asparagaceae, Araceae and Bromeliaceae (Table 1).

Within the class Liliopsida of the flora of Ukraine, the first places in species richness are occupied by seven of ten largest monocot families of the world flora, which means high representation of monocot plants of the flora of Ukraine on the familial level. The richest monocot families in the flora of Ukraine in terms of species diversity are the same three families as of the world flora, embracing totally $70-77 \%$ monocot species of the flora of Ukraine. Among the ten largest monocot families of the flora of Ukraine, capsular fruits are also found in six families (Table 1).

Table 1

Fruit types in the ten largest monocot families of the world flora and flora of Ukraine

\begin{tabular}{|c|c|c|c|c|}
\hline $\begin{array}{l}\text { The largest monocot } \\
\text { families of the world flora }\end{array}$ & $\begin{array}{l}\text { Number of genera/ } \\
\text { species in the } \\
\text { world flora }\end{array}$ & $\begin{array}{l}\text { The largest monocot families } \\
\text { of the flora of Ukraine (number } \\
\text { of genera/species in the flora of Ukraine) }\end{array}$ & $\begin{array}{l}\text { Descriptive } \\
\text { fruit type }\end{array}$ & $\begin{array}{l}\text { Principal morphological } \\
\text { characteristics of the fruit }\end{array}$ \\
\hline 1. Orchidaceae & $925 / 27135$ & Orchidaceae (29/92) & Capsule fissuricidal & $\begin{array}{l}\text { Inferior trimerous dry multi-seeded dehiscent para- } \\
\text { carpous fruit }\end{array}$ \\
\hline 2. Poaceae & $777 / 11461$ & Poaceae $(108 / 444)$ & Caryopsis & Superior dry one-seeded fruit in anthecium \\
\hline 3. Cyperaceae & $113 / 5732$ & Cyperaceae (19/153) & Cypsela & Superior dry one-seeded fruit in envelope \\
\hline 4. Asparagaceae & $143 / 3632$ & $\begin{array}{l}\text { Asparagaceae }(15 / 57) \\
\text { incl.: Agavaceae }(3 / 10) \\
\text { Asparagaceae }(1 / 8) \\
\text { Hyacinthaceae }(7 / 28) \\
\text { Ruscaceae }(4 / 11)\end{array}$ & Capsule or berry & $\begin{array}{l}\text { Superior trimerous dry multi-seeded dehiscent syncar- } \\
\text { pium or indehiscent fleshy fruit }\end{array}$ \\
\hline 5. Araceae & $113 / 3174$ & Araceae $(6 / 13)$ & Berry or utricle & $\begin{array}{l}\text { Superior oligomerous low/one-seeded fleshy indehis- } \\
\text { cent paracarpium or low/one-seeded indehiscent fruit } \\
\text { with undifferentiated pericarp }\end{array}$ \\
\hline 6. Bromeliaceae & $50 / 3160$ & Absent from the flora of Ukraine & $\begin{array}{l}\text { Berry or capsule } \\
\text { septicidal }\end{array}$ & $\begin{array}{l}\text { Inferior trimerous fleshy indehiscent fruit or dry dehis- } \\
\text { cent syncarpium }\end{array}$ \\
\hline 7. Arecaceae & $187 / 2466$ & Only in the cultural flora of Ukraine & Drupe or date & $\begin{array}{l}\text { Superior trimerous low-seeded or one-seeded fleshy } \\
\text { indehiscent apocarpium with stony endocarp, or pa- } \\
\text { pery endocarp }\end{array}$ \\
\hline 8. Iridaceae & $80 / 2182$ & Iridaceae $(4 / 34)$ & Capsule loculicidal & $\begin{array}{l}\text { Inferior trimerous dry multi-seeded dehiscent syncar- } \\
\text { pium }\end{array}$ \\
\hline 9. Amaryllidaceae & $79 / 2164$ & $\begin{array}{l}\text { Amaryllidaceae }(7 / 61) \\
\text { incl.: Agapanthaceae }(1 / 1) \\
\text { Alliaceae }(2 / 47) \\
\text { Amaryllidaceae } \text { s. s. }(4 / 13) \\
\end{array}$ & Capsule loculicidal & $\begin{array}{l}\text { Inferior or superior trimerous dry or fleshy multi- } \\
\text { seeded dehiscent syncarpium }\end{array}$ \\
\hline 10. Zingiberaceae & $52 / 1587$ & Absent from the flora of Ukraine & Capsule loculicidal & $\begin{array}{l}\text { Inferior trimerous dry multi-seeded dehiscent syncar- } \\
\text { pium }\end{array}$ \\
\hline 11. Liliaceae & $15 / 610$ & Liliaceae $(7 / 52)$ & $\begin{array}{l}\text { Capsule loculicidal } \\
\text { or berry }\end{array}$ & $\begin{array}{l}\text { Superior trimerous dry multi-seeded dehiscent syncar- } \\
\text { pium or fleshy indehiscent fruit }\end{array}$ \\
\hline 12. Juncaceae & $8 / 442$ & Juncaceae (2/41) & Capsule loculicidal & $\begin{array}{l}\text { Superior trimerous dry multi-seeded or three-seeded } \\
\text { dehiscent syncarpium or paracarpium }\end{array}$ \\
\hline 13. Potamogetonaceae & $4 / 111$ & Potamogetonaceae (1/25) & Oligo-drupe & $\begin{array}{l}\text { Superior apocarpous aggregate fruit of few one-seeded } \\
\text { indehiscent fruitlets with a stony endocarp }\end{array}$ \\
\hline
\end{tabular}

Note: families recognized after Chase et al. (2016); for the flora of Ukraine, families recognized by Mosyakin (2013) are noted; the number of genera and species in the world flora given after www.mobot.org/MOBOT/research/APweb, in the flora of Ukraine - after Mosyakin \& Fedoronchuk (1999) and Danylyk (2012) for Cyperaceae.

The survey of the published data on fruit diversity in monocots is complicated by the application of molecular genetic methods in taxonomy during the last two decades, which has substantially changed the system of the class Liliopsida. These methods have revealled substantial differences between traditional evolutionary systems of the end of the XX century and the new scenario of clade phylogenesis (Chase, 2004; Thorne \& Reveal, 
2007; Mosyakin, 2013; Chase et al., 2016). As a result, the extent of subclasses, some orders and families was changed; especially it concerns the families of the order Asparagales (Mosyakin \& Buyun, 2013). In this relation, it is desirable to analyze the fruit traits as potential synapomorphies of newly recognized clades as also to retain their representation in the flora of Ukraine.

\section{Characteristics of main fruit types in the monocots}

The names of fruit types are given based on different principles of fruit classification (Kaden, 1965; Roth, 1977; Artjuschenko \& Theodorov, 1986; Levina, 1987; Spjut, 1994; Bobrov et al., 2009; Bobrov \& Romanov, 2019). The lack of a formalized terminology in the carpological literature causes many difficulties during the analysis of multisource data for one taxon, and during comparison of data for several taxa. For instance, the phrases: "capsule inferior syncarpous dorsiventral" (Kaden, 1965), "capsule dehiscent by valves" (Takhtajan, 1985), and "capsule loculicidal" (Goldblatt et al., 1998), given for Iridaceae, have the same meaning.

To make possible the treatment of published data on the distribution of fruit types inside the class Liliopsida of the flora of Ukraine, we compiled an annotated list of names of fruit types, used in specialized home and foreign literature. This list has shown a range of diversity of fruit types in each family and the diversity of names given for fruit in each taxon. We did not examine in detail the morphogenetic (Bobrov et al., 2009; Bobrov \& Romanov, 2019) and carpological (Spjut, 1994) approaches to fruit classification because these concepts need a special discussion, however, some data cited from those works for some taxa are taken without discussion. We distributed fruit names in the annotated list according to descriptive and comparative-morphological principles (Artjuschenko \& Theodorov, 1986; Levina, 1987; Bobrov et al., 2009) into five principal fruit categories, given below. Then, we treated these categories in monocot subclasses and families.

Polymerous apocarpous fruit, aggregate fruit (ukr. zbirnyi plid) - the most primitive fruit, formed from apocarpous gynoecium of many or some carpels, correspondingly one can distinguish polymerous and oligomerous apocarpium or indicate the number of carpels in the fruit name by prefix multi-, oligo- (for example, hexamerous multi-follicle, tri-follicle). An element of the aggregate fruit is named fruitlet (ukr. plodyk), that can be many-, low-, one-seeded, dehiscent or indehiscent, with various pericarp consistency. Aggregate fruit most often can be one of three types: multi-nucula or polyachene (ukr. bahatohorishok), multi-drupe (ukr. bahatokistyanka), multi-follicle (ukr. bahatolystyanka).

Capsular fruit, capsule (ukr. korobochka) - syncarpous (as well coenocarpous and paracarpous), multi-seeded, dehiscent, dry, seldom fleshy, superior or inferior, uni-locular or multi-locular fruit, with various dehiscence modes and mechanisms, as also complicated pericarp anatomy.

Berry-like fruit, berry (ukr. yahoda) - apocarpous or syncarpous indehiscent fruit with fully unlignified fleshy pericarp. The berry can be polymerous, oligomerous or monomerous, many-, low-, one-seeded, superior or inferior.

Schizocarp (ukr. skhizokarpiy, drobnyi plid) - syncarpous low-seeded fruit splitting longitudinally into a few unicarpellate units (mericarps). Such fruit is considered to be derived from capsular fruit or pyrenarium, having an advantage in that seeds are dispersed with pericarp covering.

One-seeded fruit - unilocular fruit developed from the monomerous or pseudomonomerous gynoecium, bearing only one seed, as a rule indehiscent, with various pericarp consistency. It is the most difficult fruit type for interpretation because it is the result of reduction in the number of carpel and seeds in the apocarpous or syncarpous gynoecium. This category embraces fruits, called achene, cypsela (ukr. sim'yanka), nutlet (ukr. horishok), nut (ukr. horikh), caryopsis (ukr. zernivka), utricle (ukr. mishechok), and drupe (ukr. kistyanka). Drupaceous fruit or drupe (ukr. kistyan$\mathrm{ka}$ ), is characterized by strong differentiation of the inner mechanical zone of the pericarp, forming a stone (putamen). It is as a rule an indehiscent one-seeded fruit or fruitlet. Syncarpous drupe is called pyrenarium. Because a drupe is reliably recognized only by the anatomical study of the pericarp, which is not always taken into consideration in taxonomical works, we classified multi-drupe as an aggregate fruit and uni-drupe and pyrenarium as one-seeded fruit.

\section{Annotated list of morphological fruit types of monocot plants of the flora of Ukraine}

In this list, for all monocot families of the flora of Ukraine, the descriptive and morphological fruit traits were outlined, as also ovary insertion (superior or inferior), seed number, placentation, presence of envelope, and mode of dehiscence, if such information is known from published sources. Fruit types are presented only for genera occurring in the flora of Ukraine. Families are listed alphabetically and distributed in subclasses Alismatidae, Liliidae, and Commelinidae within the framework of Mosyakin (2013), where authors of names of taxa are given. Asterisked (*) are the families of cultural flora or those which have escaped to the wild. Alternative data for one taxon are separated by a semicolon (;). We submitted only basic sources for each family, since the informational pool for some taxa substantially exceeds the volume of a journal article.

\section{Subclass Alismatidae}

Acoraceae (Acorus) - berry syncarpous, superior, trimerous, lowseeded, with thin leathery pericarp, red, enveloped in tepals (Kaden, 1965; Takhtajan, 2009). In the natural populations, fruits do not develop remaining green, with sterile seeds inside. For Acorus a congenitally syncarpous gynoecium is characteristic, which is unexpected because this genus is recognized as a sister clade to all other monocots (Endress, 1995; Chen et al., 2004; Igersheim et al., 2008).

Alismataceae - multi-nucula with envelope: acyclic (Sagittaria) or cyclic (Alisma) (Kaden, 1965); multi-nucula of small fruitlets, sometimes with lignified endocarp (Caldesia) (Takhtajan, 1985); achenetum (Spjut, 1994); achene (Takhtajan, 2009); multi-nucula (Sagittaria), poly-laurine (Alisma), multi-drupe (Caldesia) (Bobrov et al., 2009). Laurine is considered to be a follicle-derived fruit with lignified endocarp, analogically to drupe. In Damasonium, fruit is a syncarpous multi-follicle (Takhtajan, 1985); hemisyncarpous multi-follicle with ventral dehiscence (Bobrov et al., 2009); basally dehiscent follicles (Takhtajan, 2009). In Damasonium, the transition from laminal to basal placentation is observed as also from few ovules to a single ovule (Eames, 1961); camaretum - apocarpous polymerous fruit of dry multi-seeded indehiscent fruitlets, with seeds, do not fill the whole locule volume (Spjut, 1994).

Araceae (incl. Lemnaceae) - superior berry-like one-low-seeded fruit (Takhtajan, 1985). In Calla fruit is a berry paracarpous, trimerous, noncovered, juicy, red, gathered in an infruitescence (Kaden, 1965). In Calla palustris there are 4-5 seeds in a berry (Belyakov et al., 2017). In Pistiacapsule dry indehiscent (Takhtajan, 1985); monomerous low-seeded fruit with thin half-transparent pericarp (Takhtajan, 2009). In Lemnaceae capsule paracarpous (?), superior, trimerous (?), covered, broken [punctuation as in the original text] (Kaden, 1965); monomerous fruit, 1-6-seeded utricle (Takhtajan, 2009); utriclulate indehiscent one-seeded (Lemna minor, L. trisulca) or 1-6-seeded (L. gibba) fruit with soft, membranous pericarp and a beak on place of fallen style (Takhtajan, 1985; Zhmylev et al., 1995). In Spirodela, fruit is 1-2-seeded, sometimes reddish, 1-2 mm long, with wing-like zone; monomerous achenial fruit with 1-7 seeds; utricle, a unilocular uni-seeded fruit with thin dehiscent fruit wall, releasing seeds (Spjut, 1994). Utricle, after Spjut (1994), is composed by more than one carpel. Most Lemnaceae have one-seeded fruits (Tippery \& Les, 2020).

Butomaceae (Butomus) - multi-follicle (hexa-follicle) superior, hemisyncarpous, of 6-9 fruitlets, ventrally dehiscent, with covering (Kaden, 1965); oligomerous cyclic multi-follicle of 6-9 multi-seeded fruitlets with laminal placentation (Takhtajan, 1985; Levina, 1987); dry cyclic 3-6-merous multi-follicle, ventrally dehiscent (Bobrov et al., 2009). Carpels are fused postgenitally (www.mobot.org/MOBOT/research/APweb).

Hydrocharitaceae (incl. Najadaceae) - capsule inferior, fleshy, disrupting: syncarpous, hexamerous (Hydrocharis, Stratiotes) or paracarpous trimerous (Elodea) (Kaden, 1965); inferior unilocular, berry-like indehiscent fruit or dehiscent by mucilage hydration, carpels are fused but have free margins (Takhtajan, 1985, 2009); inferior hexamerous hemiparacarpous berry (Stratiotes) or inferior hexamerous paracarpous (phragmocarpous) berry, sometimes with an envelope, fruit sometimes irregularly cracking by drying (Elodea, Hydrocharis, Vallisneria) (Bobrov et al., 2009). In Hydrocharis fruit is defined as an inferior hexamerous hemiparacar- 
pous berry, irregularly dehiscent by mucilage hydration (Efremov et al., 2015b), in Stratiotes aloides fruit is defined as an inferior hexamerous hemisyncarpous multi-follicle with unilocular ovary and incomplete septa, laminar-diffuse placentation with aerial cavities in the mesocarp (Efremov et al., 2015a); fruit fleshy, capsular/dehiscence irregular/indehiscent. The fruit may be follicular or achenial, or in Hydrocharis opening because of the mucilage developing inside it (www.mobot.org/MOBOT/ research/APweb). In Najadaceae fruit - uninucula in an envelope (apocarpous, monomerous, indehiscent fruit) (Kaden, 1965); one-seeded indehiscent fruit with thin soft pericarp (Takhtajan, 1985); uninucula (Levina, 1987; Bobrov et al., 2009); achene (Spjut, 1994); carpel is solitary (Eames, 1961); pseudomonomerous, coenocarpous nut, however, pericarp remains juicy for a long time (Singh, 1965 cit. by Bobrov et al., 2009); monomerous or pseudomonomerous fruit, superior, one-seeded, with thin transparent pericarp, closely adnated to basal seed, dehiscing by decay (Takhtajan, 2009); gynoecium ostensibly monomerous, superior, carpel oneovular, fruit non-fleshy, the fruiting carpel indehiscent, an achene, pericarp thin (www.delta-intkey.com).

Juncaginaceae (Triglochin) - fruit is a schizocarp syncarpous, superior, hexamerous, not covered (Kaden, 1965, 1971); multi-follicle of free or fused to some degree one-seeded indehiscent fruitlets; fruit splits up from the bottom to top on three particles, remaining connected for some time above by central columella. In Triglochin palustre units of fruit have a long spike (Takhtajan, 1985); schizocarpous fruit, splitting into three one-seeded indehiscent fruitlets, without columella (camarium) or columnar (polachenarium), columella is formed by three sterile carpels (Spjut, 1994); poly-achene of 3 or 6 fruitlets, sometimes basically fused, but over time splitting (Takhtajan, 2009); apocarpous fruit with elongated receptacle or schizocarp with a columella (Lock et al., 2011); schizocarpous drupe, fruitlets have lignified endocarp, barely adjoined one to another, detached from the columella during drying (Thadeo et al., 2015); fruit schizocarpic/drupaceous/achenial// (hooked, winged) (www.mobot.org/ MOBOT/research/APweb).

Potamogetonaceae (Potamogeton) - tetra-achene with a cover (apocarpous, superior, tetramerous, indehiscent fruit) (Kaden, 1965); multidrupe of 1-4 fruitlets (Takhtajan, 1985); achenetum (Spjut, 1994); fruit drupaceous (Bobrov et al., 2009; Takhtajan, 2009; Thadeo et al., 2015).

Ruppiaceae (Ruppia) - oligomerous drupe with one-seeded fruitlets, asymmetrical, pendulous on long and thin peduncles (Takhtajan, 1985, 2009; Levina, 1987; Spjut, 1994); polylaurine or oligo-laurine (Bobrov et al., 2009).

Scheuchzeriaceae (Scheuchzeria) - tri-follicle hemisyncarpous, dorsiventral dehiscent (Kaden, 1965); oligomerous cyclic follicle, carpels are fused at a base, with 1-2 seeds, remain open for a long time (Takhtajan, 1985, 2009; Levina, 1987); multi-follicle (Spjut, 1994); dry inflated multifollicle (tri-follicle), with 1-2-seeded fruitlets, to some degree fused at the base, ventrally dehiscent "from the inner side" (Minaeva, 1997); dry cyclic 3-6-merous one-low-seeded multi-follicle with ventral dehiscence (Bobrov et al., 2009); gynoecium of 3 (2-6) two-ovulate carpels, fused at the base, fruit a superior dry hemisyncarpous capsule with fertile symplicate zone, and dorsiventral dehiscence (Remizowa \& Sokoloff, 2014).

Tofieldiaceae (Tofieldia) - capsule superior syncarpous trimerous, covered, septicidal-ventrally dehiscent (Kaden, 1965); transitional type between multi-follicle and septicidal capsule (Takhtajan, 1985); capsule trimerous, septicidal, or tri-follicle (Takhtajan, 2009); carpels 3-5, stipitate, basally fused, postgenitally united in its upper portion (Eames, 1961; Remizowa et al., 2006).

Zannicheliaceae (Zannichelia) [Potamogetonaceae sensu Chase et al., 2016] - drupaceous fruit of one or few fruitlets, indehiscent, one-seeded, stipitate (Takhtajan, 1985, 2009); achenetum (Spjut, 1994); monolaurine (Bobrov et al., 2009).

Zosteraceae (Zostera) - paracarpous pseudomonomerous pyrenarium, developed from dimerous pseudomonomerous gynoecium (Cronquist, 1981); small monomerous one-seeded fruit with thin papery dehiscent fruit wall (Takhtajan, 1985; 2009), covered by a spatha, destroyed by rupture, releasing a seed (Ackerman, 1997); one-seeded brownish, noncovered, ovate, juicy follicle, 3-4 mm long, longitudinally dehiscent (Vekhov, 1992); camara, "indehiscent follicle" - apocarpous monomerous indehiscent fruit with undifferentiated pericarp, with soft exocarp and hard fibrous endocarp (Spjut, 1994); uni-drupe or uni-nucula (Bobrov et al., 2009); fruit an achene/follicle (www.mobot.org/MOBOT/research/APweb).

\section{Subclass Liliidae}

Agapanthaceae* (Agapanthus) [Amaryllidaceae sensu Chase et al., 2016] - capsule superior, trimerous, multi-seeded, loculicidal (Kubitzki, 1998a; Takhtajan, 2009).

Agavaceae (Anthericum, Hosta*, Yucca*) [Asparagaceae sensu Chase et al., 2016] - capsule superior trimerous, covered, dorsiventral (Anthericum) (Kaden, 1965); capsule superior trimerous multi-seeded loculicidal (Takhtajan, 1985); apically dehiscent (Conran, 1998a; Takhtajan, 2009). In Hosta - capsule superior, trilocular, multi-seeded, pendent, loculicidal, dehiscent from top to bottom by three valves (Takhtajan, 1985; Kubitzki, 1998b). In Yucca - capsule superior, loculicidal or septicidal (Takhtajan, 2009).

Alliaceae (Allium, Nectaroscordum) [Amaryllidaceae sensu Chase et al., 2016] - capsule superior, trilocular, low-seeded, with an envelope, leathery, dorsiventral (Kaden, 1965), or loculicidal (Takhtajan, 1985, 2009; Rahn, 1998).

Amaryllidaceae - capsule inferior, trimerous, dry or fleshy, loculicidal or fruit is fleshy berry-like, indehiscent (Takhtajan, 1985, 2009; Meerow \& Snijman, 1998).

Asparagaceae (Asparagus) - berry trimerous superior, not covered, one-low-seeded (Kaden, 1965; Takhtajan, 1985, 2009; Kubitzki \& Rudall, 1998).

Asphodelaceae (Asphodeline, Eremurus) [Xanthorrhoeaceae sensu Stevens (2017)] - capsule superior one-low-seeded, thick-walled, loculicidal (Takhtajan, 1985; 2009; Smyth \& van Wyk, 1998); capsule superior syncarpous, loculicidal, dehiscent by three apical valves (Bobrov et al., 2009).

Colchicaceae (Bulbocodium, Colchicum) - capsule superior syncarpous trimerous, covered, septicidal-ventrally dehiscent (Kaden, 1962, 1965), septicidally dehiscent (Takhtajan, 1985; Artjuschenko \& Theodorov, 1986); capsule multi-seeded, partially or totally syncarpous, septicidally dehiscent (Nordenstam, 1998).

Dioscoreaceae (Tamus) - berry inferior trimerous, with 1-6 seeds, red (Takhtajan, 1985; Levina, 1987).

Hemerocallidacae* (Hemerocallis) [Asphodelaceae sensu Chase et al., 2016] - capsule dry, leathery, trilocular, with 9-12 seeds in a locule, loculicidal (Takhtajan, 1985, 2009; Clifford, 1998).

Hyacinthaceae [Asparagaceae sensu Chase et al., 2016] - capsule superior, trimerous, loculicidal, dry or fleshy, erect or pendent, perfectly or apically dehiscent (Takhtajan, 1985; 2009; Speta, 1998).

Iridaceae - carpule syncarpous, inferior, trimerous, multi-seeded, leathery, dorsiventral (Kaden, 1962, 1965), dehiscent by valves or longitudinal fissures (Takhtajan, 1985); loculicidal capsule (Spjut, 1994; Goldblatt et al., 1998; Takhtajan, 2009).

Liliaceae - capsule syncarpous, superior, trimerous, non covered (most of the genera) or covered (Gagea), dorsiventrally dehiscent (Kaden, 1965); capsule trilocular loculicidal (Takhtajan, 1985, 2009; Spjut, 1994; Tamura, 1998b). In Streptopus - berry syncarpous superior, trilocular multi-seeded (Tamura, 1998a; Takhtajan, 2009).

Melanthiaceae (Veratrum, Paris) - tri-follicle hemisyncarpous, covered, septicidal-ventrally dehiscent (Veratrum) (Kaden, 1965); capsule multiseeded loculicidal (Takhtajan, 1985); capsule syncarpous, ventrally dehiscent, trilobate, of fused to some degree carpels, semi-inferior, multi-seeded (Tamura, 1998c; Takhtajan, 2009); capsule semi-inferior septicidal/ventricidal. In Paris - berry superior, tetramerous, covered (Kaden, 1965; Tamura, 1998d).

Orchidaceae - capsule paracarpous (sometimes syncarpous) inferior, trimerous, multi-seeded, laterally dehiscent on six valves, among them three wide "dorsal" and other three narrow "placental" valves, sometimes vice versa; valves detach from the top, or the bottom, or the middle-height, releasing seeds (Kaden, 1962, 1965); capsule unilocular, dehiscent by drying onto three or six valves, in the last case, three wider valves are "fertile", bear placentae and other three valves are "sterile" (Roth, 1977); capsule fissuricidal (Spjut, 1994).

Ruscaceae (incl. Convallariaceae) [Asparagaceae sensu Chase et al., 2016] - berry superior trimerous (Convallaria, Polygonatum) or dimerous 
(Majanthemum), non-covered (Kaden, 1965), unilocular, low-seeded (Ruscus), often red or orange (Takhtajan, 2009).

Smilacaceae* (Smilax) - berry superior trimerous, unilocular, with 1-2 seeds (Conran, 1998b; Takhtajan, 2009), or 1-3, 6 seeds (Takhtajan, 1985).

\section{Subclass Commelinidae}

Arecaceae* (Chamaerops, Trachycarpus, Phoenix)-apocarpous superior, trimerous fruit of one-seeded fruitlets, covered by lignified perigonium at a base (Eames, 1961); drupe dry or fleshy, mostly one-seeded (Takhtajan, 1985); drupe of "coryphoid" type, with early lignified mesocarp with compound many-layered structure, fruits apocarpous, rarely 2 3-merous (Chamaerops humilis), often monomerous (Trachycarpus) (Bobrov et al., 2009). In Phoenix fruit is a date - apocarpous superior mono-oligomerous one-seeded fleshy fruit, with a layer of stony cells under hypoderm and membranous endocarp (Levina, 1987; Bobrov et al., 2009). Date is a berry-like, one-seeded fruit with tanninoferous mesocarp (Roth, 1977); aggregate berry-like fruit (baccetum) (Spjut, 1994).

Cannaceae* (Canna) - capsule inferior, trilocular, multi-seeded, with soft spines outside, loculicidal, opened by valves or teeth, or indehiscent (Takhtajan, 1985); capsule opening by the collapse of the pericarp (Takhtajan, 2009); carcerula (indehiscent capsule), fissuricidal capsule (Canna indica) (Spjut, 1994).

Commelinaceae* (Commelina, Tradescantia) - capsule hemiparacarpous, superior, dimerous, enveloped, dorsiventrally dehiscent (Kaden, 1965); capsule trilocular, sometimes uni-bilocular, loculicidal (Takhtajan, 1985; 2009; Spjut, 1994).

Cyperaceae - drupe (pyrenarium) paracarpous, superior, di-trimerous, dry, non covered or covered by perigonium in a form of bristles (most genera); enveloped in utricle formed by prophyll or bract (Carex) (Kaden, 1965); fruit is nut-like, with hard pericarp, sometimes pyrenarium-like, triangular or twice convex (Takhtajan, 1985); achene with perigonium and a modified bract in a form of utricle (Carex) (Artjuschenko \& Theodorov, 1986); achene or nut, depending on lignification extent of the pericarp (Levina, 1987). In some forest sedges (Carex digitata, C. ornithopoda) the basal part of the utricle becomes fleshy, acting as elaiosome, attracting ants-disseminators (Levina, 1987); fruits achene-like or rarely drupaceous (Takhtajan, 2009); achene with perigonium in the form of bristles (cypsela) (Elaeocharis) or non-covered achene, or fruit is pseudanthecium - fruit covered by extra-floral structures (Carex) (Spjut, 1994).

Juncaceae - capsule syncarpous, superior, trimerous, covered, dorsiventrally dehiscent (Juncus) or paracarpous, dorsally dehiscent (Luzula) (Kaden, 1965); capsule loculicidal (Takhtajan, 1985, 2009; Spjut, 1994), multi-seeded (Juncus) or three-seeded (Luzula) (Takhtajan, 2009).

Musaceae* (Musa) - berry inferior, trimerous multi-seeded, elongated, with leathery exocarp; fruit expresses negative geotropic reaction by rupturing (turns up) (Roth, 1977); "rind" of a fruit easily removed due to a layer of aerial parenchyma in the fruit wall (Esau, 1977).

Poaceae - caryopsis, apocarpous, superior, monomerous fruit; it can be leptodermal with a cover (most genera), with an envelope (Zea), noncovered (e.g. Eragrostis, Secale cereale, Triticum aestivum, T. durum) (Kaden, 1965); fruit is composed of two- or three-carpellate ovary (Shelyag-Sosonko, 1977); fruit has a thin pericarp of parenchymatous outer layers, drying by maturing, and two inner mechanical layers: a subepidermal layer of cross cells and the incomplete epidermal layer of tube cells (Esau, 1977); caryopsis is a one-seeded fruit with membraneous or coriaceous pericarp, closely adjacent to the seed coat, often with longitudinal groove, sometimes with connected scales, sometimes "sac-like" (Takhtajan, 1985); nut-like paracarpous (coenocarpous) one-seeded fruit of three carpels, covered by scales (bracts and bracteoles) as also inflorescence axis. Covering can be close adjoined to caryopsis or surround it entirely, and connected with a pericarp (Artjuschenko \& Theodorov, 1986); apocarpous fruit, secondary monomerous, falls out together with spikelet scales (lemma, palea, glumes) and spikelet axis (rachilla). Caryopsis together with adjacent parts of inflorescence compose a kind of diaspore - anthecium (Levina, 1987); pseudomonomerous fruit of 2-3 carpels, ovary superior unilocular, one-seeded (Takhtajan, 1987, 2009); Spjut (1994) recognized for Poaceae besides caryopsis, another ten fruit types, most of them are variants of an anthecium; coenocarpous (paracarpous) superior dimerous one-seeded (pseudomonomerous) indehiscent nut-like fruit; sclerenchyma, often atypic, located in all pericarp layers. Caryopsis is characterized by diverse attachments (Bobrov et al., 2009). In Crypsis and Heleochloa caryopsis is follicle-like (Kaden, 1965); in Crypsis fruit is utricle-like, with a free papery fruit wall (Takhtajan, 2009).

Pontederiaceae (Monochoria) - capsule superior trimerous, multiseeded, loculicidal (Takhtajan, 2009); capsule fissuricidal (Spjut, 1994).

Sparganiaceae (Sparganium) [Typhaceae sensu Chase et al., 2016] uni-nucula in envelope (apocarpous superior fruit) (Kaden, 1965); pseudomonomerous dry drupe (Takhtajan, 1985); coenocarpous superior dry drupe in infruitescence (Levina, 1987); secondary monomerous fruit (Eckardt 1937); coenocarpous pseudomonomerous fruit, with 1-3 seeds, pyramidal, indehiscent, drupaceous, over time becomes nut-like with a spongy, seldom fleshy exocarp and hard endocarp (Takhtajan, 1987); Spjut (1994) classified fruit in Sparganium as achenosum - infruitescence of dry indehiscent one-seeded fruitlets, with thin pericarp, closely adjacent to seed; fruit with 1-2 carpels, monomerous or syncarpous (pseudomonomerous), bilocular, with one fertile and one sterile carpel, sessile, oneseeded, drupaceous or nucular, with stout exocarp, spongy mesocarp and stony endocarp (Takhtajan, 2009); superior syncarpous (pseudomonomerous) one-stoned pyrenarium; fruit is unilocular, sometimes with 2-3 sterile locules, one-seeded, rarely 2-3 seeded (Bobrov et al., 2009).

Typhaceae (Typha) - uninucula in envelop (apocarpous superior monomerous fruit) (Kaden, 1965; Bobrov et al., 2009); tiny, dry one-seeded fruit, falls with peduncle and ring of hairs, forming a fly-apparatus (Takhtajan, 1985); uninucula in infruitescence, apocarpous, secondary monomerous (Eckardt, 1937; Levina, 1987); fruit small, dry, spindle-like, coenocarpous pseudomonomerous (almost monomerous) one-seeded, splitting to the time of full ripening (Takhtajan, 1987); after Spjut (1994), fruit in Typha is a cypsela due to extragynecial structures in a form of a bundle of hairs; ovary with one hanging seed; on a stipe, elongated after anthesis, with a ring of hairs, the pericarp is membranous, two-layered (endocarp with thick-walled cells), splitting after the fruit falls in water (Mavrodiev, 1997); monomerous fruit, a follicle but tiny and achene-like before dehiscence, long stipitate, with two-layered pericarp, the inner layer with thickwalled cells (Takhtajan, 2009).

\section{Distribution of the main morphological fruit types in monocot subclasses and families}

As a result of the treatment of the published data, we revealed apocarpous polymerous or trimerous fruits (aggregate fruits) mostly with oneseeded fruitlets in six of twelve families of the subclass Alismatidae of the flora of Ukraine recognized by Mosyakin (2013). A few families have berry-like, one-seeded fruits, capsules, and schizocarp (Table 2). We did not consider as capsule some fruits in members of the Araceae and Hydrocharitaceae families, for which other fruit types were referred to in most later publications. Within 16 families of the subclass Liliidae trimerous capsules are the most common fruits in 12 families, in four families the fruit is berry-like, and two families with capsular fruit have berry-like fruits in the solitary genus (Streptopus in Liliaceae, Paris in Melanthiaceae). In some genera, deviations from trimerous groundplan occur (tetramerous fruit in Paris, dimerous fruit in Ruscus and Majanthemum of Ruscaceae). Within 10 families of the subclass Commelinidae, in four families superior dry one-seeded fruits occur (Cyperaceae, Poaceae, Sparganiaceae, Typhaceae), while another four families have trimerous capsule (Cannaceae, Commelinaceae, Juncaceae, Pontederiaceae). The families Arecaceae and Musaceae which are only cultivated in Ukraine possess drupaceous and berry-like fruits correspondingly. The most diverse subclass in terms of fruit morphology is Alismatidae, where all five main fruit types are revealed. In Commelinidae there are four main fruit types, while in Liliidae only two fruit types, capsule and berry, were revealed (Fig. 1).

Among families of the class Liliopsida of the flora of Ukraine, trimerous capsules are the most common type (17 of 38 families), occurring in all subclasses (Fig. 1). However, considering the great species richness of the Poaceae and Cyperaceae families, the most numerous fruit can be supposed to be one-seeded fruit, monocarpous or pseudomonocarpous, occurring in seven families. One-seeded fruitlets of aggregate fruits are also very common, particularly, in Alismataceae, Arecaceae, Potamoge- 
tonaceae, Ruppiaceae, Zannichelliaceae. Berries occur in 10 monocot families, however, these families are not large or there are solitary genera within families with capsular fruit. The rarest fruit type for monocot plants of Ukraine is schizocarp (Fig. 1), appearing only in one genus Triglochin (Juncaginaceae). Among the studied taxa there are no monomerous follicles, poricide and operculate capsules, winged fruits and loments revealed that occur in dicotyledonous plants (Levina, 1987). Most monocot families in the flora of Ukraine are homogenous in carpological traits. This presumably results from the fact that few taxa represent many monocot families in the flora of Ukraine. However, in six families several fruit types were revealed (Alismataceae, Araceae, Arecaceae, Hydrocharitaceae, Liliaceae, Melanthiaceae).

Table 2

Main fruit types in the monocot plants of the flora of Ukraine

\begin{tabular}{|c|c|}
\hline Fruit types & Subclasses and families \\
\hline $\begin{array}{l}\text { Aggregate } \\
\text { fruit }\end{array}$ & $\begin{array}{l}\text { Alismatidae: Alismataceae, Butomaceae, Potamogetonaceae, } \\
\text { Ruppiaceae, Scheuchzeriaceae, Zannichelliaceae } \\
\text { Commelinidae: Arecaceae* }\end{array}$ \\
\hline Capsule & $\begin{array}{l}\text { Alismatidae: Tofieldiaceae } \\
\text { Liliidae: Agapanthaceae*, Agavaceae*, Alliaceae, Amaryllidaceae, } \\
\text { Asphodelaceae, Colchicaceae, Hemerocallidacae*, Hyacinthaceae, } \\
\text { Iridaceae, Liliaceae } p . p \text {., Melanthiaceae (Veratrum), Orchidaceae } \\
\text { Commelinidae: Cannaceae*, Commelinaceae*, Juncaceae, } \\
\text { Pontederiaceae }\end{array}$ \\
\hline Berry & $\begin{array}{l}\text { Alismatidae: Acoraceae, Araceae } p . p ., \text { Hydrocharitaceae } p . p . \\
\text { Liliidae: Asparagaceae, Ruscaceae, Dioscoreaceae, Melanthiaceae } \\
\text { (Paris), Liliaceae (Streptopus), Smilacaceae* } \\
\text { Commelinidae: Musaceae* }\end{array}$ \\
\hline Schizocarp & Alismatidae: Juncaginaceae \\
\hline $\begin{array}{l}\text { One-seeded } \\
\text { fruit }\end{array}$ & $\begin{array}{l}\text { Alismatidae: Araceae p. p., Hydrocharitaceae (Najas), Zosteraceae } \\
\text { Commelinidae: Cyperaceae, Poaceae, Sparganiaceae, Typhaceae }\end{array}$ \\
\hline
\end{tabular}

Note: families recognized after Mosyakin (2013); ${ }^{*}$ - cultural flora.

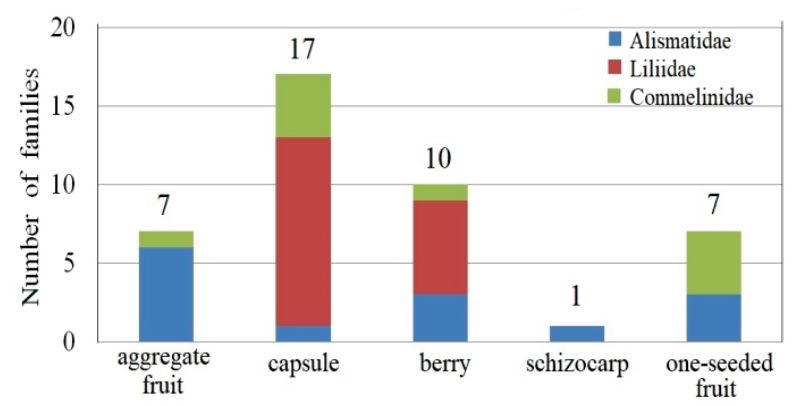

Fig. 1. Fruit types in monocot families of the flora of Ukraine: the total number of families above columns is greater than 38 because in some families two fruit types are recognized

Many monocot families have unambiguously defined fruit types, which however can differ in minor traits according to different sources. For example, the different definitions can concern the dehiscence mode of the capsule or pericarp consistency. Most of these families (15 of 27 families) belong to the subclass Liliidae and have trimerous capsular or berrylike fruits. For 11 families ( $29 \%$ of families), two or more interpretations of morphological fruit type exist. Among them, one case is a group of families with initial carpel fusion (Hydrocharitaceae (Stratiotes), Juncaginaceae, Melanthiaceae (Veratrum), Scheuchzeriaceae, Tofieldiaceae), resulting in fruit type being formed of a transitional stage between apocarpous and syncarpous and that is why it is defined as multi-follicle (apocarpous fruit) or capsule and schizocarp (syncarpous fruit). The other group of families unites families with one-seeded fruit, being treated as monomerrous apocarpium or pseudomonocarpium because of the absence of transitional stages between one-seeded and ancestral fruit (Araceae (Lemna), Cyperaceae, Hydrocharitaceae (Najas), Poaceae, Sparganiaceae, Typhaceae, Zosteraceae). In both cases, the reason for the controversial interpretation of the fruit type concerns gynoecium structure, which is still problematic (Remizowa et al., 2006, 2010; Sokoloff, 2016; Sokoloff et al., 2017). It is interesting that the Hydrocharitaceae family appears in both lists of controversial fruit types, and fruit in Stratiotes is unique through the combination of almost unfused carpels and inferior ovary (Efremov et al., 2015a). The examination of gynoecium structure and pericarp anatomy in various monocot plants of the flora of Ukraine is a ground for future research on evolutionary fruit morphology and fruit adaptations to dissemination.

\section{Conclusions}

As a result of our study, it becomes clear that the taxonomical diversity of monocotyledonous plants of the flora of Ukraine represents well the diversity of the world monocot flora, with an almost equally high portion of the largest families that define the spectrum of fruit types in the class Liliopsida. The morphological diversity of fruits within the class Liliopsi$\mathrm{da}$ in the flora of Ukraine is characterized by the predominance of trimerous capsules on the familial level and one-seeded fruits and fruitlets on the generic level. Fruits in many families have alternative names due to the lack of unified carpological terminology, different degrees of knowledge of the fruit structure and different opinions on the gynoecium and fruit classification in taxa that are problematic from the morphological viewpoints. The most controversial fruit types are in plants with one-seeded fruit (monocarpium or pseudomonocarpium). The problem also arises for the definition of fruit type in plants with initial carpel fusion. The great number of families with trimerous capsules led to the need to apply anatomical methods in the study of pericarp structure aimed at differentiating the convergent variants of fruits. Meanwhile, for the most problematic taxa, it is necessary to find principles of classification of the fruits with undefined gynoecium type. In general, the monocot plants of the flora of Ukraine are characterized by limited diversity of morphological fruit types and poor knowledge of the fruit structure, which makes further carpological studies in Ukraine a highly relevant topic for research.

The present research was fully self-funded by the authors. No competing interests have been declared.

\section{References}

Ackerman, J. D. (1997). Submarine pollination in the marine angiosperm Zostera marina (Zosteraceae). I. The influence of floral morphology on fluid flow. American Journal of Botany, 84(8), 1099-1109.

Artjuschenko, Z. T., \& Theodorov, A. A. (1986). Atlas po opisatelnoy morfologii vysshikh rasteniy. Plod [ Atlas of descriptive morphology of higher plants. Fruit] [Organographia illustrata plantarum Vascularium. Fructus]. Nauka, Leningrad (in Russian).

Balaguera-Lopez, H. E., Fischer, G., \& Magnitskiy, S. (2020). Seed-fruit relationships in fleshy fruit species: Role of hormones. A review. Revista Colombiana de Ciencias Horticolas, 14(1), 90-103.

Behren, C., \& Yeakley, J. A. (2020). Hydrochorous seed dispersal in riparian forests altered by urbanization. Ecosphere, 11(2), e03049.

Belyakov, E. A., Lapirov, A. G., \& Lebedeva, O. A. (2017). Ekologiya prorastaniya semyan i osobennosti ontogeneza splavinoobrazuyushchego gigrogelofita Calla palustris (Araceae) $\mathrm{v}$ laboratornykh usloviyakh [Ecology of seed germination and features of ontogeny of floating mat-forming hygrogelophyte Calla palustris (Araceae) under laboratory conditions]. Biosystems Diversity, 25(4), 282288 (in Russian).

Bobrov, A. V. F. C., \& Romanov, M. S. (2019). Morphogenesis of fruits and types of fruit of angiosperms. Botany Letters, 166(3), 366-399.

Bobrov, A. V., Melykyan, A. P., \& Romanov, M. S. (2009). Morfogenez plodov Magnoliophyta [Morphogenesis of fruits of Magnoliophyta]. Librokom, Moscow (in Russian).

Boedeltje, G., Ozinga, W. A., \& Prinzing, A. (2008). The trade-off between vegetative and generative reproduction among angiosperms influences regional hydrochorous propagule pressure. Global Ecology and Biogeography, 17, 50-58.

Bojňanský, V., \& Fargašová, A. (2007). Atlas of seeds and fruits of Central and EastEuropean flora the Carpathian Mountains Region. Springer, Dordrecht.

Chase, M. W. (2004). Monocot relationships: An overview. American Journal of Botany, 91(10), 1645-1655.

Chase, M. W., Christenhusz, M. J. M., Fay, M. F., Byng, J. W., Judd, W. S., Soltis, D. E., Mabberley, D. J., Sennikov, A. N., Soltis, P. S., \& Stevens, P. F. (2016). The angiosperm phylogeny group. An update of the angiosperm phylogeny group classification for the orders and families of flowering plants APG IV. Botanical Journal of the Linnean Society, 181, 1-20. 
Chen, J. M., Chen, D., Gituru, W. R., Wang, Q. F., \& Guo, Y.-H. (2004). Evolution of apocarpy in Alismatidae using phylogenetic evidence from chloroplast rbcL gene sequence data. Botanical Bulletin - Academia Sinica Taipei, 45(1), 33-40.

Clifford, H. T., Henderson, R. J. F., \& Conran, J. G. (1998). Hemerocallidaceae. In Kubitzki, K. (Ed.). The families and genera of vascular plants. III. Flowering plants: Monocotyledons: Lilianae (except Orchidaceae). Springer, Berlin, Heidelberg. Pp. 295-333.

Conran, J. G. (1998a). Anthericaceae. In: Kubitzki, K. (Ed.). The families and genera of vascular plants. III. Flowering plants: Monocotyledons: Lilianae (except Orchidaceae). Springer, Berlin, Heidelberg. Pp. 114-121.

Conran, J. G. (1998b). Smilacaceae. In: Kubitzki, K. (Ed.). The families and genera of vascular plants. III. Flowering plants: Monocotyledons: Lilianae (except Orchidaceae). Springer, Berlin, Heidelberg. Pp. 417-422.

Cronquist, A. (1981). An integrated system of classification of flowering plants. Columbia University Press, New York.

Danylyk, I. M. (2012). Systema rodyny Cyperaceae Juss. flory Ukrainy [System of the family Cyperaceae Juss. in the Ukrainian flora]. Ukrainian Botanical Journal, 69(3), 337-351 (in Ukrainian).

Dardick, C., \& Callahan, A. M. (2014). Evolution of the fruit endocarp: Molecular mechanisms underlying adaptations in seed protection and dispersal strategies. Frontiers in Plant Science, 5, 284.

Dremliuga, N. G. (2013). Morfolohichni osoblyvosti plodiv vydiv sektsii medium D.C. rodu Campanula L. flory Ukrainy [Morphological peculiarities of fruits of species from section medium DC. of genus Campanula L. in the flora of Ukraine]. Chomomorski Botanical Journal, 9(1), 24-29 (in Ukrainian)

Eames, A. J. (1961). Morphology of the Angiosperms. McGraw-Hill, New York.

Eckardt, T. (1937). Untersuchungen über Morphologie, Entwicklungsgeschichte und Systematische Bedeutung des Pseudomonomeren Gynoeceums. Nova Acta Leopoldina, 5, 1-112.

Efremov, A. N., Filonenko, A. V., \& Sviridenko, B. F. (2015a). Anatomy and morphology of reproductive organs of Stratiotes aloides L. (Hydrocharitaceae). Inland Water Biology, 8(4), 334-344.

Efremov, A. N., Filonenko, A. V., \& Toma, C. (2015b). K voprosu o strukture generativnykh organov predstaviteley Hydrocharis L. (Hydrocharitaceae) [The question of generative organs structure of representatives of the genus Hydrocharis L. (Hydrocharitaceae)]. In: Lapirov, A. G., Philippov, D. A., \& Garin, E V. (Eds.). Hydrobotany 2015: Proceedings of VII All-Russian conference with international participation on aquatic macrophytes. I. D. Papanin Institute for Biology of Inland Waters RAS. Filigran, Yaroslavl. Pp. 9-13.

Endress, P. K. (1995). Major evolutionary traits of monocot flowers. In: Rudall, P. J., Cribb, P. J., Cutler, D. F., \& Humphries, C. J. (Eds.). Monocotyledons: Systematics and evolution. Royal Botanic Gardens, Kew, Richmond. Pp. 43-79.

Esau, K. (1977). Anatomy of seed plants. 2nd ed. John Wiley and Sons, New York.

Famiani, F., Bonghi, C., Chen, Z.-H., Drincovich, M. F., Farinelli, D., Lara, M. V Proietti, S., Rosati, A., Vizzotto, G., \& Walker, R. P. (2020). Stone fruits: Growth and nitrogen and organic acid metabolism in the fruits and seeds $-\mathrm{A}$ review. Frontiers in Plant Science, 11, 1-16.

Favre-Bac, L., Lamberti-Raverot, B., Puijalon, S., Emoult, A., Burel, F., Guillard, L., \& Mony, C. (2017). Plant dispersal traits determine hydrochorous species tolerance to connectivity loss at the landscape scale. Journal of Vegetation Science, 28, 605-615.

Goldblatt, P., Manning, J. C., \& Rudall, P. (1998). Iridaceae. In: Kubitzki, K. (Ed.) The families and genera of vascular plants. III. Flowering plants: Monocotyledons: Lilianae (except Orchidaceae). Springer, Berlin, Heidelberg. Pp. 295-333.

Igersheim, A., Buzgo, M., \& Endress, P. K. (2008). Gynoecium diversity and systematics in basal monocots. Botanical Joumal of the Linnean Society, 136(1), 1-65.

Ilyinska, A. P. (2016). Spektry morfolohichnykh oznak Brassicaceae s. 1.: Plid, nasinyny [The range of morphological characters of Brassicaceae s. 1.: Fruit and seeds]. Ukrainian Botanical Journal, 73(3), 219-233 (in Ukrainian).

Jordaan, L. A., Johnson, S. D., \& Downs, C. T. (2011). The role of avian frugivores in germination of seeds of fleshy-fruited invasive alien plants. Biological Invasions, 13, 1917-1930.

Kaden, N. N. (1962). Tipy prodolnogo vskryvaniya plodov [The types of longitudinal fruit dehiscence]. Botanical Journal, 47(4), 495-505 (in Russian).

Kaden, N. N. (1965). Tipy plodov rasteniy sredney polosy evropeyskoy chasti SSSR [The fruit types of plants inhabiting the middle zone of the European part of the USSR]. Botanical Journal, 50(6), 775-787 (in Russian).

Kaden, N. N. (1971). Semeystvo Juncaginaceae Lindl. [Family Juncaginaceae Lindl. Arrowgrass family]. In: Kaden, N. N. (Ed.). Morphology of fruits and seeds of some weed plants of USSR. Uchenye Zapiski Moskovskogo Oblastnogo Pedinstituta, Botanika, 292(5), 30-32 (in Russian).

Karimi, S., Hemami, M. R., Tarkesh Esfahani, M., \& Baltzinger, C. (2020). Endozoochorous dispersal by herbivores and omnivores is mediated by germination conditions. BMC Ecology, 20, 49.

Kravtsova, T. I. (2015). On some regularities of one-seeded fruits evolution. Journal of Life Sciences, 9, 511-520.
Kubitzki, K. (1998a). Agapanthaceae. In: Kubitzki, K. (Ed.). The families and genera of vascular plants. III. Flowering plants: Monocotyledons: Lilianae (except Orchidaceae). Springer, Berlin, Heidelberg. Pp. 58 60

Kubitzki, K. (1998b). Hostaceae. In: Kubitzki, K. (Ed.). The families and genera of vascular plants. III. Flowering plants: Monocotyledons: Lilianae (except Orchidaceae). Springer, Berlin, Heidelberg. Pp. 256-260.

Kubitzki, K., \& Rudall, P. J. (1998). Asparagaceae. In: Kubitzki, K. (Ed.). The families and genera of vascular plants. III. Flowering plants: Monocotyledons: Lilianae (except Orchidaceae). Springer, Berlin, Heidelberg. Pp. 125-129.

Latowski, K., Szkudlarz, P., \& Toma, C. (2015). Morfologia, anatomia i taksonomia owoców i nasion: Bibliografia polskich prac karpologicznych z komentarzem Morphology, anatomy and taxonomy of fruits and seeds: Bibliography of Polish carpological works with a comment]. Prace Zakładu Taksonomii Roślin UAM w Poznaniu - Publiations of the Department of Plant Taxonomy of the Adam Mickiewicz University in Poznan, 19. Poznań (in Polish).

Lebedeva, O. A., Belyakov, E. A., \& Lapirov, A. G. (2020). Reproductive potential of yellow water-lily (Nuphar lutea) in the conditions of lake ecosystems. Biosystems Diversity, 28(1), 60-67.

Levina, R. E. (1957). Sposoby rasprostaneniya semyan i plodov [Methods of dispersal of seeds and fruits]. Nauka, Moscow (in Russian).

Levina, R. E. (1987). Morfologiya i ekologiya plodov [Morphology and ecology of fruits]. Nauka, Leningrad (in Russian).

Lock, I. E., Remizowa, M. V., von Mering, S., Köcke, A. V., \& Sokoloff, D. D. (2011). Flower and fruit anatomy in African Triglochin (Juncaginaceae: Alismatales). In: Demidov, A. S. (Ed.). Carpology and reproductive biology of higher plants: Proceedings of the Russian conference with international participation dedicated to the memory of Professor A. P. Melikian. Astra-Polygraphia Moscow. Pp. 144-145.

Mavrodiev, E. V. (1997). Typha angustifolia. In: Pavlov, V. N., \& Tikhomirov, V.N. (Eds.). Biological flora of the Moscow region. Poliex, Moscow, 13. Pp. 4-29 (in Russian)

Meerow, A. W., \& Snijman, D. A. (1998). Amaryllidaceae. In: Kubitzki, K. (Ed.). The families and genera of vascular plants. III. Flowering plants: Monocotyledons: Lilianae (except Orchidaceae). Springer, Berlin, Heidelberg. Pp. 83-110.

Minaeva, N. Y. (1997). Scheuchzeria palustris. In: Pavlov, V. N., \& Tikhomirov, V.N. (Eds.). Biological flora of the Moscow region. Poliex, Moscow, 13 Pp. 30-49 (in Russian).

Mosyakin, S. L. (2013). Rodyny i poryadky kvitkovykh roslyn flory Ukrainy: Prahmatychna klasyfikatsiya ta polozhennya u filohenetychniy systemi [Families and orders of angiosperms of the flora of Ukraine: A pragmatic classification and placement in the phylogenetic system]. Ukrainian Botanical Journal, 70(3), 289-307 (in Ukrainian).

Mosyakin, S. L., \& Buyun, L. I. (2013). Problema Asparagales sensu APG: Suchasnyi pohlyad na makrosystematyku klyuchovoi hrupy odnodolnykh [Problem of Asparagales sensu APG: Modern views on macrosystematics of a key group of monocots]. In: Buyun, L. I., Ivannikov, R. V., \& Kovalska, L. A. (Eds.). Fundamental and applied aspects of modern orchidology. Knyhonosha, Kyiv. Pp. 116-126 (in Ukrainian).

Mosyakin, S. L., \& Fedoronchuk, M. M. (1999). Vascular plants of Ukraine. A nomenclatural checklist. M. G. Kholodny Institute of Botany, National Academy of Sciences of Ukraine, Kiev.

Nevo, O., \& Ayasse, M. (2020). Fruit scent: Biochemistry, ecological function, and evolution. In: Mérillon, J. M., \& Ramawat, K. G. (Eds.). Co-evolution of secondary metabolites. Springer Nature Switzerland. Pp. 1-23.

Nordenstam, B. (1998). Colchicaceae. In: Kubitzki, K. (Ed.). The families and genera of vascular plants. III. Flowering plants: Monocotyledons: Lilianae (except Orchidaceae). Springer, Berlin, Heidelberg. Pp. 175-185.

Pesotskaya, V. V., Chaplygina, A. B., Shupova, T. V., \& Kratenko, R. I. (2020). Fruit and berry plants of forest belts as a factor of species diversity of ornithofauna during the breeding season and autumn migration period. Biosystems Diversity, 28(3), 290-297.

Pijl, van der L. (1982). Principles of dispersal in higher plants. Ed. 3. Springer, Berlin, Heidelberg, New York.

Rahn, K. (1998). Alliaceae. In: Kubitzki, K. (Ed.). The families and genera of vascular plants. III. Flowering plants: Monocotyledons: Lilianae (except Orchidaceae). Springer, Berlin, Heidelberg. Pp. 70-78

Remizowa, M. V., \& Sokoloff, D. D. (2014). O stroenii ploda Scheuchzeria palustris (Sheuchzeriaceae, Alismatales) [Fruit structure in Scheuchzeria palustris (Sheuchzeriaceae, Alismatales)]. In: Lotova, L. I., \& Timonin, A. C. (Eds.). Kaden's Memorial Book [Book in Memory of Prof. Kaden]. MAKS Press, Moscow. Pp. 173-181 (in Russian).

Remizowa, M. V., Sokoloff, D. D., \& Rudall, P. J. (2006). Evolution of the monocot gynoecium: Evidence from comparative morphology and development in Tofieldia, Japonolirion, Petrosavia and Narthecium. Plant Systematics and Evolution, 258, 183-209.

Remizowa, M. V., Sokoloff, D. D., \& Rudall, P. J. (2010). Evolutionary history of the monocot flower. Annals of the Missouri Botanical Garden, 97, 617-645. 
Roth, I. (1977). Fruits of Angiosperms. In: Zimmermann, W., Carlquist, S., Ozenda, P., \& Wulff, H. D. (Eds.). Encyclopedia of plant anatomy. G. Borntraeger, Berlin.

Sena, F. H., Schulz, K., Cierjacks, A., Falcão, H. M., Lustosa, B. M., Almeida, J. S. (2021). Goats foster endozoochoric dispersal of exotic species in a seasonally dry tropical forest ecosystem. Journal of Arid Environments, 188, 104473.

Shelyag-Sosonko, Y. R. (Ed.). (1977). Zlaki Ukrainy [Grasses of Ukraine: Anatomical-morphological karyosystematical and ecological-phytocoenotical review]. Naukova Dumka, Kyiv (in Russian).

Smyth, G. F., \& van Wyk, B. E. (1998). Asphodelaceae. In: Kubitzki, K. (Ed.). The families and genera of vascular plants. III. Flowering plants: Monocotyledons: Lilianae (except Orchidaceae). Springer, Berlin, Heidelberg. Pp. 130-140.

Sokoloff, D. D. (2016). Correlations between gynoecium morphology and ovary position in angiosperm flowers: Roles of developmental and terminological constraints. Biology Bulletin Reviews, 6(1), 84-95.

Sokoloff, D. D., Nuraliev, M. S., Oskolski, A. A., \& Remizowa, M. V. (2017). Gynoecium evolution in angiosperms: Monomery, pseudomonomery, and mixomery. Moscow University Biological Sciences Bulletin, 72(3), 97-108.

Speta, F. (1998). Hyacinthaceae. In: Kubitzki, K. (Ed.). The families and genera of vascular plants. III. Flowering plants: Monocotyledons: Lilianae (except Orchidaceae). Springer, Berlin, Heidelberg. Pp. 261-285.

Spjut, R. W. (1994). A systematic treatment of fruit types. Memoirs of the New York Botanical Garden, 70, 1-182.

Takhtajan, A. (1987). Sistema magnoliofitov [Systems of Magnoliophyta]. Nauka, Leningrad (in Russian).

Takhtajan, A. (2009). Flowering Plants. 2 ed. Springer, Science+Business Media B.V.

Takhtajan, A. (Ed.). (1985). Sravnitelnaya anatomiya semyan [Comparative seed anatomy], 1. Liliopsida seu Monocotyledones. Nauka, Leningrad (in Russian).

Tamura, M. N. (1998a). Calochortaceae. In: Kubitzki, K. (Ed.). The families and genera of vascular plants. III. Flowering plants: Monocotyledons: Lilianae (except Orchidaceae). Springer, Berlin, Heidelberg. Pp. 164-172.

Tamura, M. N. (1998b). Liliaceae. In: Kubitzki, K. (Ed.). The families and genera of vascular plants. III. Flowering plants: Monocotyledons: Lilianae (except Orchidaceae). Springer, Berlin, Heidelberg. Pp. 343-353.
Tamura, M. N. (1998c). Melanthiaceae. In: Kubitzki, K. (Ed.). The families and genera of vascular plants. III. Flowering plants: Monocotyledons: Lilianae (except Orchidaceae). Springer, Berlin, Heidelberg. Pp. 369-380.

Tamura, M. N. (1998d). Trilliaceae. In: Kubitzki, K. (Ed.). The families and genera of vascular plants. III. Flowering plants: Monocotyledons: Lilianae (except Orchidaceae). Springer, Berlin, Heidelberg. Pp. $444-452$.

Teryokhin, E. S. (2000). Plod [The fruit]. In: Batygina, T. B. (Ed.). Embryology of flowering plants. Terminology and concepts, 3. Reproductive systems. World and Family, Saint Petersburg. Pp. 289-295 (in Russian).

Thadeo, M., Hampilos, K. E., \& Stevenson, D. W. (2015). Anatomy of fleshy fruits in the Monocots. American Joumal of Botany, 102(11), 1-23.

Thorne, R. F., \& Reveal, J. L. (2007). An updated classification of the class Magnoliopsida ("Angiospermae"). The Botanical Review, 73(2), 67-182.

Tippery, N. P., \& Les, D. H. (2020). Tiny plants with enormous potential: Phylogeny and evolution of duckweeds. In: Cao, X. H., Fourounjian, P., \& Wang, W. (Eds.). The duckweed genomes, compendium of plant genomes. Springer, Nature, Switzerland. Pp. 19-38.

Vekhov, V. N. (1992). Zostera morskaya (Zostera marina L.) Belogo morya [Common eelgrass (Zostera marina L.) of the White Sea]. MGU, Moscow (in Russian).

Volkova, O. A., Remizowa, M. V., Sokoloff, D. D., \& Severova, E. E. (2016). A developmental study of pollen dyads and notes on floral development in Scheuchzeria (Alismatales: Scheuchzeriaceae). Botanical Journal of the Linnean Society, 182, 791-810.

Zhmylev, P. Y., Krivokharchenko, I. S., \& Shcherbakov, A. V. (1995). Semeystvo Lemnaceae [Family Lemnaceae]. In: Pavlov, V. N., \& Tikhomirov, V. N. (Eds.). Biological Flora of the Moscow region. Argus, Moscow, 10. Pp. 20-51 (in Russian).

Ziman, S. M., \& Bulakh, O. V. (2013). Anatomo-morfolohichni doslidzhennya sudynnykh roslyn v Ukrayini: Rozvytok i suchasnyy stan [Anatomical and morphological studies of the vascular plants in Ukraine: Development and modern state]. Ukrainian Botanical Journal, 70(1), 54-60 (in Ukrainian). 